\title{
Feeding rate for pacu reared in net cages
}

\section{Cleonice Cristina Hilbig ${ }^{1}$, Wilson Rogério Boscolo², Aldi Feiden², Fabiana Dieterich ${ }^{3}$, Evandro Kleber Lorenz ${ }^{1}$, Micheli Zaminhan ${ }^{2}$}

\author{
1 Universidade Estadual do Oeste do Paraná - UNIOESTE/Campus de Marechal Cândido Rondon. \\ 2 Universidade Estadual do Oeste do Paraná - UNIOESTE/Campus de Toledo. \\ ${ }^{3}$ Universidade Estadual Júlio de Mesquita Filho -UNESP - Centro de Aquicultura da UNESP/CAUNESP - Jaboticabal/SP.
}

\begin{abstract}
The objective of this study was to evaluate the feeding management of pacu juveniles (P. mesopotamicus) under different feeding rates and its relation with productive performance, body composition and hematological characteristics. A total of 300 fish with initial weight of $84.75 \pm 4.52 \mathrm{~g}$ were distributed in a completely randomized design composed of four treatments (100, 90, 80 and 70\% of feed supply) and five repetitions. The amount of feed was stipulated according to the quantity supplied in the treatment until apparent satiation (100\%) of the day before. The decrease in the feeding rate to $70 \%$ over satiation apparently improves the apparent feed conversion without harming performance, body composition or biochemical and hematological characteristics of pacu juveniles reared in net cages.
\end{abstract}

Key Word: amount of feed, feeding management, intensive aquaculture, native species

\section{Introduction}

Rearing fish in net cages is a super intensive technique (Gontijo, 2008) and the diet represents about 30 to $60 \%$ of the operational costs of this system (Huguenin, 1997). Thus, such high cost must be minimized with an efficient feeding management, in order to maximize yield, and consequently, profit.

The amount of feed supplied to a species is mainly affected by water temperature and quality and the growth phase (Kubitza, 1997). This daily fraction of feed supplied to fishes aiming to promote better efficiency must be lower than the maximum intake capacity (Halver, 1972); however, it must be above the level utilized for maintenance (Hardy, 1998).

When underfed, fishes worsen their development; there is increase in competition for feed, and also the possibility of making animals more susceptible to diseases (Rowland et al., 2005). On the other hand, excess can compromise the feed conversion and, indirectly, provoke metabolicdigestive alterations, not to mention the monetary losses, caused by the non-consumed feed (Meurer et al., 2005).

Another effect caused by variation in the feeding rate is on fish body composition, in which the lipid contents can be altered in such a way that when elevating the feeding rates, their contents also increase (Du et al., 2006), being able to generate increase of visceral fat and decrease carcass yield.
Pacu (Piaractus mesopotamicus, Holmberg, 1887) is a native species widely found in the basins of rivers Paraná, Paraguay and Uruguay. This species is of great importance to aquaculture, for it presents quick growth, rusticity to handling, easy adaptation to artificial feeding and great acceptance by the consumer market (Urbinati \& Gonçalves, 2005). Its adaptability to the system of net-cage rearing was proven by Signor et al. (2010), who studied the relation between protein and energy and by Bittencourt et al. (2010), who verified the best stocking density for the pacu reared in net cages.

The objective of this study was to evaluate the influence of the feeding rate on productive performance, body composition and hematological variables of pacu juveniles reared in net cages.

\section{Material and Methods}

The experiment was conducted in the period from November 2008 to February 2009, in the transitional area of the reservoir from Itaipu Binacional, located at Centro de Desenvolvimento de Tecnologias para Piscicultura em Tanque-rede (Center of Development of Technologies for Fish Farming in Net Cages), in the Biological Refuge of the municipality of Santa Helenta, Paraná, close to the boundary of Brazil with Paraguay (240.5' S and 54 $37^{\prime} \mathrm{W}$ ), with a duration of 78 days. 
A total of 300 fishes with initial average weight of approximately $84.75 \pm 4.52 \mathrm{~g}$ were distributed in a completely randomized design in twenty net cages with $0.49 \mathrm{~m}^{2}$ area and useful volume of $0.34 \mathrm{~m}^{3}$. The cage containing fifteen fishes, with density of 44 fishes $/ \mathrm{m}^{3}$ was considered an experimental unit.

Treatments were constituted of four different feeding rates, as follows: treatment 1 : feed supplied up to apparent satiation (100\%); treatments 2, 3 and 4 corresponded to the supply of 90,80 and $70 \%$ of the amount of feed consumed the day before by fish from treatment 1 , respectively.

A commercial extruded diet with $32 \%$ crude protein, $5 \%$ lipids and $3,500 \mathrm{kcal} / \mathrm{kg}$ digestible energy was utilized. Feeding was performed three times a day (9, 13 and 17h).

Biometry was performed at 23 and 50 days. For so, net cages were brought close to the margin, and with the aid of a hand net, animals were collected and conditioned in a container filled with water with benzocaine $(75 \mathrm{mg} / \mathrm{L})$ for further weighing.

Physical and chemical parameters, $\mathrm{pH}$, electrical conductivity $(\mu \mathrm{S} / \mathrm{cm})$ and dissolved oxygen $(\mathrm{mg} / \mathrm{L})$ from the water were measured monthly through digital potentiometers, whereas temperature $\left({ }^{\circ} \mathrm{C}\right)$ and transparency (m) of the water were monitored daily in the morning and afternoon, with the aid of a thermometer and Secchi disk.

At the end of the experimental period, fishes underwent fasting for 24 hours, and five animals of each net cage were collected for blood analyses. Fishes were anesthetized with Eugenol ${ }^{\circledR}$ solution $(60 \mathrm{mg} / \mathrm{L})$, according to protocol proposed by Barbosa et al. (2007). Subsequently, by puncture of the tail vein, $2.0 \mathrm{~mL}$ of blood were collected from each animal, with the aid of a disposable syringe containing EDTA (10\%). This aliquot was destined to counting the number of erythrocytes in a Neubauer chamber under optical microscope with 40-time magnifying lens.

After dilution of the blood with Hayem's solution, the determination of hemoglobin and hematocrit was performed according to methodology described by Collier (1944) and Goldenfarb et al. (1971), respectively. Mean corpuscular volume (MCV), mean corpuscular hemoglobin $(\mathrm{MCH})$ and concentration of mean corpuscular hemoglobin $(\mathrm{CMCH})$ were calculated through the results obtained and determined according to the RBC indices of Wintrobe (1934).

For biochemical evaluations of total glucose, triglycerides and protein, the serum which was immediately separated by centrifugation was utilized. Analyses were conducted utilizing the enzymatic-colorimetric method with spectrophotometer.

After blood collection, all animals were anesthetized (100 mg/L benzocaine) for measurement of biomass gain
(BG), final weight (FW), weight gain (WG), daily weight gain (DWG), survival rate (SR), apparent feed conversion (AFC) and specific growth rate $[\mathrm{SGR}=100 \mathrm{x}$ (ln final average weight - $\ln$ initial average weight)/period (days)]. Total intake and cost with the feeding supplied throughout the experiment were calculated as well.

After, for evaluation of carcass yield as eviscerated fish (EF), clean trunk (CT), filet (FL), hepatosomatic (HSI) and visceral fat index (VFI), five animals were selected randomly per tank, then anesthetized ( $250 \mathrm{mg} / \mathrm{L}$ benzocain), preserved in ice and transported to the Laboratório de Tecnologia de Peixes of Universidade Estadual do Oeste do Paraná/Campus Toledo.

Next, samples of filets were separated for the characterization of the centesimal composition of filets as for moisture (MO), crude protein ( $\mathrm{CP})$, ether extract (EE) and mineral matter (MM) according to the AOAC (2005).

Statistical analyses were performed by means of software SAEG (version 7.1). The results were submitted to variance analysis, adopting $\alpha=0.05$. Orthogonal decomposition of the sum of squares of treatments in linear, quadratic and cubic effects in function of decrease in the feeding rate was performed, according to the best fitting obtained for each variable.

\section{Results and Discussion}

The values of minimum and maximum temperature, $\mathrm{pH}$, dissolved oxygen and electrical conductivity and transparency were $27.7 \pm 0.9^{\circ} \mathrm{C}$ and $29.0 \pm 1.1^{\circ} \mathrm{C} ; 7.36 \pm 0.06$; $7.03 \pm 0.45 \mathrm{mg} / \mathrm{L} ; 41 \pm 3.5 \mu \mathrm{S} / \mathrm{cm}$ and $2.5 \pm 0.6 \mathrm{~m}$, respectively. These values remained within the recommended range for farming fish of tropical climate regions (Boyd, 1990; Sipaúba-Tavares, 1995).

The survival rate recorded was $100 \%$, and performance means of pacu $P$. mesopotamicus juveniles under different feeding rates reared in net cages did not differ $(\mathrm{P}>0.05)$, except for apparent feed conversion (Table 1).

The non-significant effect on weight gain can be explained by the fact that fish subjected to the low feeding rate maximize digestion and absorption, in order to extract the maximum nutrients from the feed and convert them into growth (Eroldogan et al., 2004; Kim et al., 2007). The final weights recorded are not marketable, because the size of net cages $(0.7 \times 0.7 \mathrm{~m})$ affects growth, so the experiment was ended at 78 days.

Apparent feed conversion worsened $(\mathrm{P}<0.01)$ according to increase in feeding intake; the best results were obtained for the treatment with $70 \%$ feeding (Figure 1). 
Table 1 - Mean values of performance parameters of pacu (P. mesopotamicus) juveniles and summary of variance analysis, in function of different feeding rates

\begin{tabular}{|c|c|c|c|c|c|c|c|c|}
\hline \multirow{2}{*}{ Item } & \multicolumn{4}{|c|}{ Feeding rate $(\%)$} & \multicolumn{3}{|c|}{ P Value } & \multirow{2}{*}{$\mathrm{CV}(\%)$} \\
\hline & 100 & 90 & 80 & 70 & Linear & Quadratic & Cubic & \\
\hline Biomass gain $(\mathrm{g})$ & 4680.92 & 4456.83 & 4231.20 & 4187.17 & 0.0724 & 0.1887 & 0.3513 & 10.2 \\
\hline Final weight $(\mathrm{g})$ & 395.41 & 381.17 & 370.49 & 360.56 & 0.0977 & 0.8821 & 0.9646 & 8.2 \\
\hline Weight gain $(\mathrm{g})$ & 312.06 & 297.12 & 282.08 & 279.15 & 0.0865 & 0.6644 & 0.8394 & 10.0 \\
\hline Daily weight gain (g) & 4.00 & 3.81 & 3.62 & 3.57 & 0.0865 & 0.6644 & 0.8394 & 10.0 \\
\hline Apparent feed conversion ${ }^{1}$ & 2.51 & 2.40 & 2.22 & 1.96 & 0.0006 & 0.4182 & 0.9765 & 8.8 \\
\hline Specific growth rate $\left(\%\right.$ day $\left.^{-1}\right)$ & 1.99 & 1.93 & 1.90 & 1.83 & 0.0722 & 0.1236 & 0.2718 & 4.6 \\
\hline Feed intake $(\mathrm{kg})^{2}$ & 11.53 & 10.38 & 9.22 & 8.07 & - & - & - & - \\
\hline Cost $(\mathrm{R} \$)^{3}$ & 10.26 & 9.24 & 8.21 & 7.18 & - & - & - & - \\
\hline
\end{tabular}

$\mathrm{CV}$ - coefficient of variation.

${ }_{1}^{1}$ Linear effect $\mathrm{y}=0.6981+0.0186 \mathrm{x}: \mathrm{R}^{2}=0.97$.

2 Total feed intake per net cage;

${ }^{3}$ Cost with feeding per net cage, considering $1 \mathrm{~kg}=$ BRL 0.89 .

One fact observed is the absence of feed intake for up to two days right after biometry, in all treatments.

With the results of fish weight obtained from biometrics and feed intake during the experiment, calculated through the formula $(\%$ Live weight $=$ feed intake $\times 100 /$ fish weight $)$, a feeding rate can be suggested for pacu reared in net cages (Table 2).

The feeding rate values in relation to live weight (Table 2) decreased according to the growth of fish, which was already observed by Halver (1972), corroborating the observations in the present study. These recommended values are superior to those found by Schmittou (1993), who stated that, for tilapia (O. niloticus) with average weight of 200,250,300 and $400 \mathrm{~g}$, the ideal daily feed supply would be $2.8 ; 2.5 ; 2.3$ and $2.0 \%$ of the live weight, respectively.

The data obtained by Chagas et al. (2007) when they evaluated different feeding rates (1.0, 3.0 and 5.0) for tambaqui (Colossoma macropomum) reared in net cages revealed higher averages $(\mathrm{P}<0.05)$ of weight gain for fish subjected to the rate of 3.0 and $5.0 \%$ feeding when compared with animals subjected to $1.0 \%$ feeding. On the other hand, the authors described that the best results of apparent feed conversion (AFC) were obtained with fish under $1.0 \%$ feeding, for at 3.0 and $5.0 \%$, the AFC indices found were 4.86 and 7.07 , respectively, and these values are superior to those of the present experiment.

However, Salaro et al. (2008) found a feeding rate for trairao (Hoplias lacerdae) juveniles of $4.0 \%$, which promoted higher weight gain, when compared with 2.0 and $6.0 \%$; the latter achieved the worst daily weight gain rates and consequently, the worst feed conversion.

Specific growth rate also did not differ (Table 1), and the values are close to those found by Bicudo et al. (2009) when analyzing different levels of protein and digestible energy for pacu (P. mesopotamicus) (1.9 to $2.2 \%$ per day $^{-1}$ ).
Analyzing feed intake and its costs, one can observe a saving of $30 \%$ for the treatment for up to $70 \%$ feeding rate.

The results of carcass yield did not present significant differences $(\mathrm{P}>0.05)$ between treatments (Table 3$)$. Bittencourt et al. (2010) found similar values for pacu fishes of approximately one kilogram, for the eviscerated fish ( 87 to $88 \%$ ). However, for clean trunk (60\%) and filets (45 to $47 \%$ ), they were superior to the observations in the present study.

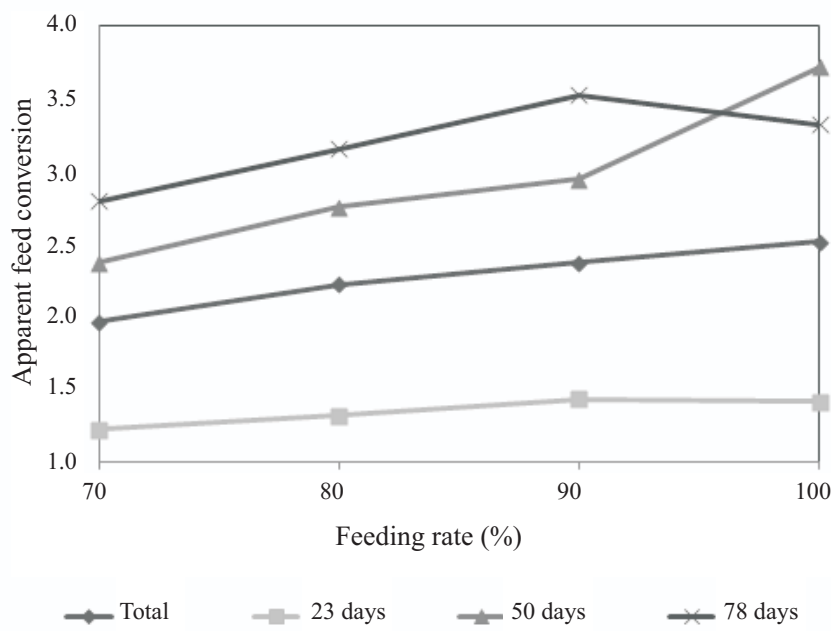

Figure 1 - Total feed conversion $\left.(y=0.6981+0.0186 x) R^{2}=0.97\right)$ and per periods of 23 days $\left.(\mathrm{y}=0.7483+0.00703 \mathrm{x}) \mathrm{R}^{2}=0.83\right)$, 50 days $(\mathrm{y}=0.5497+0.041 \mathrm{x}) \mathrm{R}^{2}=0.92$ and non-significant at 78 days, of pacu (P. mesopotamicus) juveniles reared in net cages, under different feeding rates.

Table 2 - Recommendation for feeding rate per weight class for pacu fish reared in net cages utilizing diet with $32 \%$ crude protein in the extruded form with temperatures between 27 and $30^{\circ} \mathrm{C}$

\begin{tabular}{lcc}
\hline Weight $(\mathrm{g})$ & $\begin{array}{l}\text { Recommended feeding } \\
\text { rate }(30 \% \text { restriction })\end{array}$ & $\begin{array}{c}\text { Intake until apparent } \\
\text { satiation }(100 \%)\end{array}$ \\
\hline 210 & 3.6 & 5.0 \\
295 & 2.7 & 3.6 \\
365 & 2.2 & 3.0 \\
\hline
\end{tabular}


Filet yield is above the values obtained by Basso et al. (2011), for pacu (P. mesopotamicus) reared in land ponds, who found a value of $30.11 \%$, and the weight range of the fish analyzed were from 310 to $385 \mathrm{~g}$. On the other hand, lower yield is observed when compared with the values previously determined by Faria et al. (2003) for the same species, whose results varied from 46.73 to $51.60 \%$, with filet cuts with and without skin, respectively, utilizing fish with average weight of $1958.0 \pm 164.0 \mathrm{~g}$. Such discrepancy in the filet yield values is related to the filleting method and also to the differences in weight ranges. The filet yield values determined in this experiment were for filet cuts performed after evisceration, removal of head, fins and skin.

The hepatosomatic (HSI) and visceral-somatic (VSFI) fat indices did not present significant differences $(\mathrm{P}>0.05)$ between treatments. However, they differed from those observed by Takahashi et al. (2011) (HIS from 1.8 to $2.2 \%$ and VSFI from 2.0 to $3.0 \%$ ), probably because fish were subjected to alternate feeding restriction and feedback loops.

The alteration in VSFI can be related to the mobilization of fat, in order to obtain energy when fish are under prolonged fasting, which did not occur in the present experiment, once, with adequate supply, fish have little necessity to mobilize endogenous energy (Cook et al., 2000). On the other hand, the values of visceral fat found in this experiment showed to be inferior to those found by Bombardelli et al. (2007), who achieved 6.55\% VSFI for pacu (P. mesopotamicus) in net cages.
The centesimal composition values of filets did not present significant differences $(\mathrm{P}>0.05)$ between treatments (Table 4).

Body composition values did not differ between treatments; however, other authors, such as Kim et al. (2007), have observed that for flounder (Paralichthys olivaceus), lipid values in the whole body were higher with increase in feeding rate, utilizing a diet with $52.5 \% \mathrm{CP}$ and $11.3 \%$ lipids. Du et al. (2006), in turn, with daily feeding levels $(1.0 ; 1.5 ; 2.0 ; 2.5$ and $3.0 \%)$ for grass carp (Ctenopharyngodon idella) juveniles, found differences in moisture, protein and lipids in the filet, and the lower the feeding level, the lower were the values for such parameters.

Animals reared in net cages subjected to different feeding rates did not present statistical differences between treatments for the hematological or biochemical values found (Table 5).

Although the hematological variables did not present differences $(\mathrm{P}>0.05)$ between the different treatments, the mean values of hematocrits, hemoglobin, $\mathrm{MCV}, \mathrm{CMHC}$ and MHC found are superior to those expressed by RanzaniPaiva et al. (1999), when they evaluated the hematological parameters of pacu (P. mesopotamicus) and observed mean values of $29.5 \% ; 7.3 \mathrm{~g} / \mathrm{dL} ; 176.6 \mathrm{fL} ; 25.0 \mathrm{~g} / \mathrm{dL}$ and $44.3 \mathrm{~g} / \mathrm{dL}$, respectively. However, for erythrocytes, the values reported by these authors $(1.67 \times 106 / \mu \mathrm{L})$ are superior to those observed in the present experiment

The decrease in the mean hematocrit values in tambaqui (C. macropomum) characterizes anemia (Chagas \& Val, 2003),

Table 3 - Mean values of carcass yield parameters of pacu (P. mesopotamicus) juveniles and summary of variance analysis, in function of different feeding rates

\begin{tabular}{|c|c|c|c|c|c|c|c|c|}
\hline \multirow{2}{*}{ Item } & \multicolumn{4}{|c|}{ Feeding rate $(\%)$} & \multicolumn{3}{|c|}{ P Value } & \multirow{2}{*}{ CV $(\%)$} \\
\hline & 100 & 90 & 80 & 70 & Linear & Quadratic & Cubic & \\
\hline Eviscerated fish & 88.70 & 88.45 & 88.52 & 87.52 & 0.5241 & 0.7564 & 0.7973 & 3.0 \\
\hline Clean trunk & 54.38 & 55.27 & 54.76 & 54.42 & 0.9320 & 0.5258 & 0.7141 & 3.9 \\
\hline Filet & 42.66 & 42.03 & 42.56 & 41.52 & 0.3574 & 0.7613 & 0.3806 & 3.6 \\
\hline Hepatosomatic index & 0.83 & 0.76 & 0.79 & 0.71 & 0.3266 & 0.9228 & 0.5506 & 20.7 \\
\hline Visceral fat & 5.96 & 5.28 & 5.75 & 5.57 & 0.6511 & 0.4851 & 0.2737 & 13.8 \\
\hline
\end{tabular}

$\mathrm{CV}$ - coefficient of variation.

Table 4 - Body composition of filets from pacu (P. mesopotamicus) juveniles and summary of variance analysis in function of different feeding rates

\begin{tabular}{|c|c|c|c|c|c|c|c|c|}
\hline \multirow{2}{*}{ Item } & \multicolumn{4}{|c|}{ Feeding rate $(\%)$} & \multicolumn{3}{|c|}{ P Value } & \multirow{2}{*}{$\mathrm{CV}(\%)$} \\
\hline & 100 & 90 & 80 & 70 & Linear & Quadratic & Cubic & \\
\hline Moisture & 724.2 & 720.6 & 720.4 & 718.0 & 0.4089 & 0.9139 & 0.8021 & 3.5 \\
\hline Ether extract & 81.7 & 79.6 & 93.9 & 83.8 & 0.3639 & 0.4427 & 0.0894 & 25.9 \\
\hline Crude protein & 161.5 & 157.7 & 163.0 & 158.8 & 0.8177 & 0.9490 & 0.1495 & 8.8 \\
\hline Mineral matter & 16.3 & 16.2 & 15.4 & 17.0 & 0.8089 & 0.4576 & 0.5536 & 33.4 \\
\hline
\end{tabular}

${ }^{1} \mathrm{~g} / \mathrm{kg}$ natural matter; $\mathrm{CV}$ - coefficient of variation. 
Table 5 - Hematological and biochemical variables of pacu (P. mesopotamicus) reared in net cages and summary of variance analysis, in function of different feeding rates

\begin{tabular}{|c|c|c|c|c|c|c|c|c|}
\hline \multirow{2}{*}{ Item } & \multicolumn{4}{|c|}{ Feeding rate $(\%)$} & \multicolumn{3}{|c|}{ P Value } & \multirow{2}{*}{ CV $(\%)$} \\
\hline & 100 & 90 & 80 & 70 & Linear & Quadratic & Cubic & \\
\hline \multicolumn{9}{|l|}{ Hematological } \\
\hline Hemoglobin (g/dL) & 10.41 & 10.74 & 10.68 & 10.86 & 0.3960 & 0.8177 & 0.6628 & 6.7 \\
\hline Hematocrits $(\%)$ & 36.76 & 36.4 & 36.36 & 37.24 & 0.5972 & 0.3015 & 0.8202 & 3.5 \\
\hline Erythrocytes $(106 / \mu \mathrm{L})$ & 1.49 & 1.38 & 1.32 & 1.43 & 0.3962 & 0.1148 & 0.7168 & 10.8 \\
\hline $\operatorname{MCV}(f L)$ & 247.3 & 267.78 & 279.67 & 261.77 & 0.3071 & 0.1151 & 0.6841 & 9.8 \\
\hline MHC (g/dL) & 28.38 & 29.51 & 29.40 & 29.15 & 0.5731 & 0.4407 & 0.7579 & 6.5 \\
\hline $\mathrm{MCH}(\mathrm{g} / \mathrm{dL})$ & 70.32 & 78.45 & 82.22 & 76.24 & 0.1997 & 0.0673 & 0.7418 & 10.5 \\
\hline \multicolumn{9}{|l|}{ Biochemical } \\
\hline Glucose (mg/dL) & 83.25 & 98.18 & 98.46 & 101.52 & 0.0981 & 0.4096 & 0.5860 & 16.4 \\
\hline Cholesterol (mg/dL) & 176.29 & 184.39 & 163.37 & 179.75 & 0.8319 & 0.7118 & 0.1958 & 14.0 \\
\hline Triglycerides (mg/dL) & 304.55 & 360.65 & 293.56 & 341.04 & 0.7415 & 0.8789 & 0.0890 & 17.7 \\
\hline Total protein $(\mathrm{g} / \mathrm{dL})$ & 3.70 & 3.78 & 3.63 & 3.74 & 0.9507 & 0.8938 & 0.2694 & 5.8 \\
\hline
\end{tabular}

$\mathrm{CV}$ - coefficient of variation; $\mathrm{MCV}$ - mean corpuscular volume; $\mathrm{CMCH}$ - concentration of mean corpuscular hemoglobin; $\mathrm{MCH}$ - mean corpuscular hemoglobin.

which was not observed in this experiment, in which pacu were subjected to different feeding rates. However, Cho et al. (2006) obtained significant differences in hematocrit values when feeding rates were reduced from 100 to $70 \%$; the values found for these levels ranged from 43.1 to $35.7 \%$, respectively, for flounder (Paralichthys olivaceus) juveniles.

The results for glucose are elevated in relation to the experiment conducted by Bicudo et al. (2009), who evaluated diets with protein:energy ratio for growing pacu. These authors found minimum and maximum glucose values of $65.80 \pm 12.10$ and $80.11 \pm 16.23 \mathrm{mg} / \mathrm{dL}$, respectively. The hyperglycemia found in the present study can be related to the management of animal capture and to their transportation to the place of conduction of blood sampling procedures, where net cages were taken to the border of the reservoir and fish were collected with a hand net. However, they are close to the values found by Bittencourt et al. (2010), who achieved 99.95 to $106.55 \mathrm{mg} / \mathrm{dL}$ in pacu with different densities; these authors utilized the same methodology of capturing animals.

The cholesterol levels found in this study were superior to those verified by Baldan (2004), who evaluated chrome supplementation in the diet during 30 and 60 days for pacu; these authors obtained mean values of $137.7 \pm 1.17$ and $108.4 \pm 1.34 \mathrm{mg} / \mathrm{dL}$, respectively.

In this study, the feed supply in all treatments was enough to meet the quantitative requirements of pacu, so there was no need for mobilization of proteins, which was also observed by Chagas et al. (2007), with tambaqui (C. macropomum) reared in net cages under different feeding rates, who obtained average values of glucose, triglycerides and protein of $60.09 \pm 2.20 \mathrm{mg} / \mathrm{dL} ; 216.15 \pm 76.23 \mathrm{mg} / \mathrm{dL}$; and $2.45 \pm 0.44 \mathrm{~g} / \mathrm{dL}$, respectively. Although with values inferior to those obtained in the present study, they also did not find significant differences in these biochemical parameters.

\section{Conclusions}

Decreasing the feeding rate to up to $70 \%$ over apparent satiation improves apparent feed conversion without harming performance, body composition or biochemical and hematological characteristics of pacu juveniles reared in net cages.

\section{Acknowledgements}

The authors would like to thank Itaipu Binacional and UNIOESTE/Campus Toledo, which, through Convênio de Cooperação-Técnico-Financeiro, under no.CV4500008796, enabled the conduction of this study.

\section{References}

ASSOCIATION OF OFFICIAL ANALYTICAL CHEMISTRY AOAC. Official methods of analysis of the AOAC. 18.ed. Gaithersburg, M.D, USA, 2005.

BALDAN, A.P. Suplementação de cromo na dieta, utilização de carboidrato e desempenho produtivo do pacu (Piaractus mesopotamicus). 2004. 47f. Dissertação (Mestrado em Aquicultura) - Universidade Estadual Paulista "Júlio de Mesquita Filho", Jaboticabal.

BARBOSA, L.G.; MORAES, G.L.; INOUE, AK. A. Respostas metabólicas do matrinxã submetido à banhos anestésicos do eugenol. Acta Scientiarum Biological Sciences, v.29, p.255-260, 2007. BASSO, L.; FERREIRA, M.W.; SILVA, A.R. Efeito do peso ao abate nos rendimentos dos processamentos do pacu (Piaractus mesopotamicus). Arquivo Brasileiro de Medicina Veterinária e Zootecnia, v.63, p.1260-1262, 2011.

BICUDO A.J.A.; SADO, R.Y.; CYRINO J.E.P. Growth and haematology of pacu, Piaractus mesopotamicus, fed diets with varying protein to energy ratio. Aquaculture Research, v.40, p.486-495, 2009. 
BITTENCOURT, F.; FEIDEN, A.; SIGNOR, A.A. et al. Densidade de estocagem e parâmetros eritrocitários de pacus criados em tanques-rede. Revista Brasileira de Zootecnia, v.39, p.2323-2329, 2010

BOMBARDELLI, R.A.; BENCKE B.C.; SANCHES, E.A. Processamento da carne do pacu (Piaractus mesopotamicus) cultivado em tanques-rede no reservatório de Itaipu. Acta Scientiarum Animal Sciences, v.29, p.457-463, 2007.

BOYD, C.E. Water quality in ponds for aquaculture. Alabama: Birmingham Publishing, 1990. 482p.

CHAGAS, E.C.; VAL, A.L. Efeito da vitamina C no ganho em peso e em parâmetros hematológicos de tambaqui. Pesquisa Agropecuária Brasileira, v.38, p.397-402, 2003.

CHAGAS, E.C.; GOMES, L.C.; MARTINS JUNIOR, H. et al. Produtividade de tambaqui criado em tanque-rede com diferentes taxas de alimentação. Ciência Rural, v.37, p.1109-1115, 2007.

CHO, S.H.; LEE, S.; PARK, B.H. et al. Effect of feeding ratio on growth and body composition of juvenile olive flounder Paralichthys olivaceus fed extruded pellets during the summer season. Aquaculture, v.251, p.78-84, 2006.

COLLIER, H.B. The standardization of blood haemoglobin determinations. Canadian Mediacal Association Journal, v.50, p.550-552, 1944 .

COOK, J.T.; SUTTERLIN, A.M.; MCNIVEN, M.A. Effect of food deprivation on oxygen consumption and body composition of growth-enhanced transgenic Atlantic salmon (Salmo salar). Aquaculture, v.188, p.47-63, 2000.

DU, Z-Y.; LIU, Y-J.; TIAN, L-X. et al. The influence of feeding rate on growth, feed efficiency and body composition of juvenile grass carp (Ctenopharyngodon idella). Aquaculture International, v.14, p.247-257, 2006.

EROLDOGAN, O.T.; KUMLU, M.; AKTAS, M. Optimum feeding rates for European sea bass Dicentrachus labrax L. reared in seawater and freshwater. Aquaculture, v.231, p.501-515, 2004.

FARIA, R.H.S.; SOUZA, M.L.R.; WAGNER, P.M. et al. Rendimento do processamento da tilápia do Nilo (Oreochromis niloticus Linnaeus, 1757) e do pacu (Piaractus mesopotamicus, Holmberg, 1887). Acta Scientiarum, v.25, p.21-24, 2003.

GOLDENFARB, P.B.; BOWYER, F.P.; HALL, E. et al Reproducibility in the hematology laboratory: the microhematocrit determination. American Journal of Clinical Pathology, v.56, p.35-39, 1971

GONTIJO, V.P.M.; OLIVEIRA, G.R; CARDOSO, E.L. et al. Cultivo de tilápias em tanques-rede. Belo Horizonte: EPAMIG, 2008. 44p. (Boletim Técnico, 86)
HALVER, J.F. Salmonid husbandry techniques. In: HALVER, J.F. (Ed.) Fish Nutrition Academic Press. New York and London, 1972. 719p.

HARDY R.W. Feeding salmon and trout. In: Nutrition and feeding of fish. Boston: Kluwer Academic Publishers, 1998. p.175-197.

HUGUENIN, J. The design, operations and economics of cage culture systems. Aquacultural Engineering, v.16, p.167-203, 1997.

KIM, K.-D.; KANG, Y.J.; KIM, K.-W. Effects of feeding rate on growth and body composition of juvenile flounder, Paralichthys olivaceus. Journal of the World Aquaculture Society, v.38, p.169-173, 2007.

KUBITZA, F. Nutrição e alimentação dos peixes. Piracicaba: Escola Superior de Agricultura Luiz de Queiroz, 1997. 74p.

MEURER, F.; HAYASHI, C.; BOSCOLO, W.R. et al. Nível de arraçoamento para alevinos de lambari-do-rabo-amarelo (Astyanax bimaculatus). Revista Brasileira de Zootecnia, v.34, p.1835-1840, 2005.

RANZANI-PAIVA, M.J.T.; SALLES, F.A.; EIRAS, J.C. et al. Análises hematológicas de curimbatá (Prochilodus scrofa), pacu (Piaractus mesopotamicus) e tambaqui (Colossoma macropomum) das estações de piscicultura do instituto de pesca, estado de São Paulo. Boletim do Instituto de Pesca, v.25, p.77-83, 1999.

ROWLAND, S.J.; ALLAN, G.L.; MIFSUD, C. et al. Development of a feeding strategy for silver perch, Bidyanus bidyanus (Mitchell), based on restricted rations. Aquaculture Research, v.36, p.1429-1441, 2005.

SALARO, A.L.; LUZ, R.K.; SAKABE, R. et al. Níveis de arraçoamento para juvenis de trairão (Hoplias lacerdae). Revista Brasileira de Zootecnia, v.37, p.967-970, 2008.

SCHMITTOU, H.R. High density fish culture in low volume cages. Singapore: American Soybean Association, 1993. 78p.

SIGNOR, A.A.; BOSCOLO, W.R.; FEIDEN, A. et al. Proteína e energia na alimentação de pacus criados em tanques-rede. Revista Brasileira de Zootecnia, v.39, p.2336-2341, 2010.

SIPAÚBA-TAVARES, L.H.S. Limnologia aplicada à aquicultura. Jaboticabal: FINEP, 1995. 70p.

TAKAHASHI, L.S.; BILLER J.D.; CRISCUOLO-URBINATI, E. et al. Feeding strategy with alternate fasting and refeeding:effects on farmed pacu production. Journal of Animal Physiology and Animal Nutrition, v.95, p.259-266, 2011.

URBINATI, E.C.; GONÇALVES, F.D. Pacu (Piaractus mesopotamicus). In: BALDISSEROTO, B.; GOMES, L.C. (Eds.) Espécies nativas para piscicultura no Brasil. Santa Maria: Editora UFSM, 2005. 470p.

WINTROBE, M.M. Variations in the size and hemoglobin content of erythrocytes in the blood of various vertebrates. Folia Hematologica, v.51, p.32-49, 1934 